\title{
ANALISIS KEMAMPUAN BANK SYARIAH DI INDONESIA \\ DALAM MEMENUHI KEWAJIBAN JANGKA PENDEK \\ (Studi pada Bank Syariah yang telah melakukan IPO di BEJ)
}

\author{
Oleh : \\ Jamal Lullail*)
}

\begin{abstract}
Secara institusional, dalam tahun 2004 jumlah bank yang melaksanakan kegiatan usaha berdasarkan prinsip syariah meningkat menjadi tiga bank umum syariah. Bila pada awalnya bank Muamalat Indonesia yang melakukan kegiatan usaha berdasarkan prinsip syariah maka, tahun-tahun berikutnya menyusul bank Syariah Mandiri dan bank Syariah Mega Indonesia ikut andil dalam memberikan layanan dengan konsep syariah. Kelahiran bank syariah di Indonesia diperkuat dengan dikeluarkannya UU no.10 tahun 1998, baik dari aspek kelembagaan maupun aspek landasan operasional, UU no.23 tahun 1999 dari aspek landasan hukum pengembangan bank syariah. Dalam UU tersebut, dinyatakan bahwa Bank Indonesia dapat menerapkan kebijakan moneter berdasarkan prinsip-prinsip syariah, sehingga Bank Indonesia dapat mempengaruhi likuiditas perekonomian melalui bank-bank syariah. Sejak dikeluarkannya perangkat UU Perbankan Syariah, telah terjadi perubahan di dalam sistem perbankan di Indonesia, menjadi sistem perbankan berganda "dual banking system" yaitu dengan adanya dua sistem perbankan yang berjalan bersamasama (bank konvensional dan bank syariah).
\end{abstract}

Bank syariah sebagai lembaga intermediary keuangan diharapkan dapat menampilkan diri secara baik. Gambaran mengenai kinerja perbankan syariah dapat dikenali dari laporan keuangan yang dilaporkannya. Tujuan dari laporan keuangan tersebut adalah untuk menyediakan informasi menyangkut posisi keuangan, kinerja serta perubahan posisi keuangan. Tujuan dari penelitian ini adalah untuk menggambarkan perkembangan kemampuan bank syariah di Indonesia dalam memenuhi kewajiban jangka pendek. Hasil penelitian ini adalah sebagai berikut :

Pertama, kemampuan bank dalam membayar kembali simpanan nasabah saat ditarik kembali dengan alat likuid (cash ratio) yang dimiliki dan besarnya diatas rata-rata industri perbankan syariah pada tahun 2001 dan tahun 2002 adalah bank Syariah Mega Indonesia. Pada tahun 2003, cash ratio bank syariah yang besarnya melebihi rata-rata industri perbankan syariah adalah bank Mandiri Syariah dan bank Muamalat Indonesia. Sedangkan pada tahun 2004, cash ratio bank syariah yang besarnya diatas rata-rata industri perbankan syariah adalah bank Syariah Mega Indonesia. Kedua, kemampuan rata-rata perbankan syariah dalam memenuhi Giro wajib minimum (reserve requirement) sudah melebihi standar dari Bank Indonesia, yaitu 5\%. Namun pada tahun 2001 dan tahun 2002 reserve requirement bank Syariah Mega Indonesia dan bank Muamalat Indonesia pada tahun 2002 mendekati nilai $5 \%$. Di tahun-tahun berikutnya terlihat bahwa ke dua bank berusaha untuk menambah reserve requirement yang dimilikinya. Ketiga, rasio antara seluruh jumlah kredit yang diberikan oleh bank dengan dana yang diterima bank pada tahun 2001 rata-rata dibawah 80\%. Pada tahun 2002 bank Muamalat LDR nya melebihi angka 80\%. Pada tahun 2003 bank syariah yang LDRnya melebihi standar normal adalah bank Syariah Mega Indonesia. Sedangkan tahun 2004 bank Mandiri Syariah LDRnya melampaui 80\%. LDR tertinggi dicapai oleh bank Syariah Mega Indonesia. Batas ambang 80\% menunjukkan tingkat kerawanan dan kemampuan suatu bank. Semakin besar rasio ini maka semakin besar pula tingkat resiko yang dimiliki oleh bank. Bank syariah berusaha menekan LDR nya, penekanan ini sebagai indikasi bahwa bak ingin mengurangi resiko dana pada saat dana yang berasal dari pinjaman masyarakat ditarik dari bank. Keempat, 
kemampuan loan to assets pada tahun 2001 dan tahun 2002 yang melebihi rata-rata industri perbankan syariah adalah Bank Mandiri Syariah dan bank Muamalat Indonesia. Hal ini mencerminkan bahwa bank mampu memenuhi permintaan kredit dengan menggunakan total assets yang dimilikinya diatas rata-rata industrinya. Sedangkan pada tahun 2003 LAR bank syariah yang nilainya diatas rata-rata industri adalah bank Syariah Mega Indonesia. Tahun 2004 kemampuan LAR bank Syariah Mandiri dan bank Muamalat meningkat lagi diatas rata-rata industri. 


\section{PENDAHULUAN}

\section{A. Latar Belakang}

Tahun 2005 yang baru saja dilalui merupakan masa yang penuh dengan dinamika dan tantangan dalam pengembangan perbankan syariah, khususnya berkaitan dengan kondisi perekonomian nasional yang walaupun tumbuh relative tinggi pada triwulan I2005, namun pertumbuhan ekonomi cenderung melambat dengan kestabilan makroekonomi sejak triwulan II-2005 dengan menurunnya kinerja neraca pembayaran, melemahnya nilai tukar rupiah, dan tingginya inflasi mempengaruhi pula perkembangan perbankan syariah khususnya dari sisi penghimpunan dana dan penyaluran pembiayaan. Kondisi ini juga terefleksi dalam pertumbuhan industri perbankan syariah yang tidal lgi secepat periode fast growth pada tahun sebelumnya. (Laporan perkembangan perbankan syariah, $2005: 1)$

Dari aspek hukum, perkembangan bank syariah didasari dengan dikeluarkannya UU No. 7 Tahun 1992 tentang perbankan. Namun dalam UU tersebut, belum terkandung landasan hukum yang kuat terhadap pengembangan bank syariah, karena belum menyatakan secara tegas kata "prinsip syariah" dalam kegiatan perbankan. Dalam UU tersebut, baru diungkapkan istilah bank bagi hasil, yang sebenarnya belum mencakup secara tepat pengertian bank syariah yang memiliki cakupan lebih luas dari bagi hasil. Ketentuan operasional juga belum tercantum dalam UU No.7 Tahun 1992 tersebut.

Dikeluarkannya UU No. 10 Tahun 1998 kemudian memberikan landasan yang lebih kuat, baik dari aspek kelembagaan maupun aspek landasan operasional. UU No. 23 Tahun 1999, memperkuat landasan hukum pengembangan bank syariah. Dalam UU tersebut, dinyatakan bahwa Bank Indonesia dapat menerapkan kebijakan moneter berdasarkan prisip-prinsip syariah, sehingga Bank Indonesia dapat mempengaruhi likuiditas perekonomian melalui bank-bank syariah. Sejak dikeluarkannya perangkat UU Perbankan Syariah, telah terjadi perubahan di dalam sistem perbankan di Indonesia, menjadi sistem perbankan berganda "dual banking system" yaitu dengan adanya dua sistem perbankan yang berjalan bersama-sama (bank konvensional dan bank syariah).

Sejak terbukanya peluang pengembangan bank syariah, sampai dengan akhir tahun 2005 terdapat tiga bank umum syariah yang telah melakukan initial public ofering (IPO), yaitu bank Mega Syariah Indonesia, bank Syariah Mandiri Indonesia, dan bank Muamalat Indonesia. Dari data tersebut menunjukkan bahwa pangsa dan volume usaha perbankan syariah nasional masih sangat kecil dibandingkan dengan perbankan nasional. 
Dengan modal UU dan nilai-nilai moral, perbankan syariah harus mampu membuktikan keberadaannya dapat melayani kebutuhan masyarakat baik dari sisi surplus spending unit maupun deficit spending unit. Namun demikian dalam pengembangan bank syariah tidak dapat hanya berlandaskan pada aspek legalitas melalui keberadaan UU dan keunggulan nilai-nilai moral semata yang diaplikasikan dalam operasi bank syariah, namun juga harus berlandaskan pada market driven..

Bank syariah sebagai lembaga intermediary keuangan diharapkan dapat menampilkan dirinya secara baik dibandingkan dengan bank konvensional.Gambaran tentang baik buruknya bank syariah dapat dikenali melalui kinerjanya yang tergambar dalam laporan keuangan. Tujuan laporan keuangan pada sektor perbankan syariah adalah untuk menyediakan informasi yang menyangkut posisi keuangan, kinerja serta perubahan posisi keuangan, aktivitas operasi bank yang bermanfaat dalam pengambilan keputusan.

\section{B. Rumusan Masalah}

Dari paparan latar belakang diatas, maka rumusan masalah dalam penelitian ini adalah "Bagaimanakah kemampuan bank syariah di Indonesia dalam memenuhi kewajiban jangka pendek."

\section{Tujuan Penelitian}

Untuk menggambarkan kemampuan bank syariah di Indonesia dalam memenuhi kewajiban jangka pendek.

\section{Manfaat Penelitian}

Hasil penelitian ini diharapkan dapat membawa manfaat sebagai berikut:

1. Memberikan pandangan yang lebih jauh kepada peneliti dan sumbangan referensi bagi penelitian selanjutnya

2. Memberikan tambahan informasi untuk investor maupun calon investor mengenai kinerja keuangan perbankan syariah.

\section{F. Ruang Lingkup Penelitian}

1. Bank Syariah di Indonesia yang diteliti dalam penelitian ini adalah bank syariah yang telah melakukan IPO (Initial Public Offering) di Bursa Efek Jakarta., yaitu Bank Muamalat Indonesia, Bank Syariah Mandiri, Bank Syariah Mega Indonesia 
2. Perkembangan Likuiditas perbankan Syariah yang dianalisa mulai periode 2001 sampai dengan 2004 dengan menggunakan tehnik analisa rasio perbankan.

\section{TINJAUAN TEORITIS}

\section{A. Tinjauan me ngenai Bank Syariah}

Istilah "bank syariah" secara formal baru ditemui dalam Peraturan Bank Indonesia Nomor: 5/3/PBI/2003, tanggal 4 Pebruari 2003. Pasal 1 angka 1 Peraturan tersebut memberikan definisi bank syariah sebagai berikut: "Bank Syariah adalah Bank Umum sebagaimana dimaksud dalam Undang-undang Nomor 7 tahun 1992 tentang Perbankan sebagaimana telah diubah dengan Undang-Undang Nomor 10 Tahun 1998, yang melakukan kegiatan usaha berdasarkan prinsip syariah, termasuk Unit Usaha Syariah". Dalam Ensiklopedi Hukum Islam, bank Islam didefinisikan sebagai lembaga keuangan yang usaha pokoknya memberikan kredit dan jasa-jasa lain dalam lalu lintas pembayaran serta peredaran uang yang pengoperasiannya disesuaikan dengan prinsip syariat Islam. (Dahlan, 1999;194)

Tentang kegiatan bank syariah ini Sjahdeini (1999:1) menjelaskan:

"Seperti halnya bank konvensional, bank syariah juga berfungsi sebagai suatu lembaga intermediasi (intermediary institution), yartu mengerahkan dana dari masyarakat dan menyalurkan kembaii dana-dana tersebut kepada masyarakat yang membutuhkannya dalam bentuk fasilitas pembiayaan. Bedanya adalah bahwa bank syariah melakukan kegiatan " usahanya tidak berdasarkan bunga (interest free), tetapi berdasarkan prinsip syariah, yaitu prinsip pembagian keuntungan dan kerugian (profit and loss sharing principle) atau atau disingkat dengan PLS principle"

Lembaga keuangan syariah menerapkan ketentuan-ketentuan dalam kegiatan operasionalnya, yaitu :

a.Menjauhkan diri dari kemungkinan adanya unsur riba, caranya :

i. Menghindari penggunaan sistem yang menetapkan dimuka secara pasti keberhasilan suatu usaha (QS.Luqman, ayat :34)

ii. Menghindari penggunaan sistem prosentasi untuk pembebanan biaya terhadap hutang atau pemberian imbalan terhadap simpanan yang mengandung unsur melipat gandakan secara otomatis hutang/simpanan tersebut hanya karena berjalannya waktu (QS. AliImron, 130) 
iii. Menghindari penggunaan sistem perdagangan/penyewaan barang ribawi dengan imbalan barang ribawi lainnya dengan memperoleh kelebihan baik kuantitas maupun kualitas (HR. Muslim Bab Riba No 1551 s/d 1567)

iv. Menghindari penggunaan sistem yang menetapkan dimuka tambahan atas hutang yang bukan atas prakarsa yang mempunyai hutang secara sukaarela (HR. Muslim, Bab Riba No. 1569 s/d 1572)

b. Menerapkan sistem bagi hasil dan jual beli

Dengan mengacu pada Al-Qur'an surat Al-Baqarah ayat 275 dan An-Nisa ayat 29, maka setiap transaksi kelembagaan syariah harus dilandasi atas dasar sistem bagi hasil dan perdagangan atau transaksinya didasari oleh adanya pertukaran adanya uang dan barang. Akibatnya pada kegiatan muamalah berlaku prinsip ada barang/jasa uang dan barang, sehingga akan mendorong produksi barang/jasa, mendorong kelancaran arus barang/jasa, dapat dihindari adanya penyalahgunaan kredit, spekulasi, dan inflasi.

\section{B. Sumber Dana Bank Syariah}

Dana merupakan uang tunai yang dimiliki atau dikuasai oleh bank dalam bentuk aktiva atau aktiva lain yang dapat segera diubah menjadi uang tunai (Arifin,2003:50). Pertumbuhan setiap bank sangat dipengaruhi oleh perkembangan kemampuannya menghimpun dan dari mas yarakat. Adapun sumber dana bank syariah terdiri dari :

a. Modal inti (core capital)

Modal inti merupakan dana modal sendiri yang berasal dari para pemegang saham bank yaitu pemilik bank. Dimana modal ini terdiri dari modal yang disetor oleh para pemegang saham, laba bank yang tidak dibagi (cadangan) yang disisihkan untuk menutup timbulnya risiko kerugian yang mungkin timbul dikemudian hari, dan laba yang seharusnya dibagikan kepada pemegang saham tetapi melalui RUPS (Rapat Umum Pemegang Saham) diputuskan untuk ditanam kembali (laba ditahan).

b. Kuasi ekuitas (mudharabah account)

Bank menghimpun dana bagi-hasil atas dasar prinsip mudharabah. Dalam hal ini bank bertindak sebagai mudharib, yaitu pihak yang mengelola dana.

c. Titipan (wadi 'ah)

Merupakan dana pihak ketiga yang dititipkan pada bank, yang umumnya berupa giro dan tabungan dengan prinsip wadi 'ah yad dhamanah (dimana bank berhak menggunakan dana tersebut untuk kegiatan komersial tanpa menjanjikan imbalan 
apapun pada pemilik dana, sedangkan pemilik dana dapat menarik kembali simpanannya sewaktu-waktu).

\section{Laporan Keuangan Bank Syariah}

Laporan keuangan merupakan informasi yang diharapkan mampu memberikan bantuan kepada pengguna untuk membuat kcputusaii ekonomi yang bersifat financial, (Weston \& Copeland, 1995:25). Pendapat lain menyebutkan bahwa laporan keuangan adalah hasil akhir dan proses pencatatan yang merupakan suatu rangkaian dari transaksi keuangan yang terjadi selama tahun buku yang bersangkutan, (Baridwan, 1992:17).Jadi dapat disimpulkan bahwa laporan keuangan adalah hasil akhir dari proses pencatatan transaksi keuangan yang terjadi selama tahun buku yang bersangkutan yang diharapkan dapat memberikan bantuan kepada pengguna dalam membuat keputusan ekonomi yang bersifat finansial.

Tujuan laporan keuangan selain memberikan informasi yang akurat, juga untuk melihat secara jelas perubahan posisi keuangan dari waktu ke waktu untuk kepentingan analisis kondisi keuangan dan pengambilan keputusan baik bagi, manajemen, pemegang saham maupun pihak lain yang berkepentingan dengan bank. Oleh karena itu, laporan keuangan wajib di umumkan kepada publik paling lambat empat bulan setelah berakhirnya tahun laporan. Adapun tujuan pelaporan keuangan dalam konsep Islam adalah:

1.Penentuan pendapatan dan penilaian kekayaan (assets) sebagai dasar penunaian pembayaran zakat.

2.Untuk membuktikan telah terjadi transaksi (muamalah) maka harus dilakukan pencatatan.

3.Mencegah terjadinya manipulasi transaksi atau hasil dari transaksi bisnis.

4.Memberikan informasi kepada pemakai yang bermanfaat dalam pembuatan keputusan, (Zulkifli \& Sulastiningsih, 1998:175).

Perangkat laporan keuangan lengkap yang harus diterbitkan oleh bank-bank Islam adalah:

1.Laporan posisi keuangan (neraca)

2.Laporan laba-rugi

3.Laporan arus kas

4.Laporan perubahan modal pemilik dan laporan laba ditahan

5.Laporan perubahan investasi terbatas 
6.Laporan sumber dan penggunaan dana zakat dan dana sumbangan (apabila bank bertanggungjawab atas pengumpulan dan pembagian zakat)

\section{Laporan sumber dan penggunaan dana qard}

8.Catatan-catatan laporan keuangan

9. Pernyataan, laporan dan data lain yang membantu dalam menyediakan informasi yang diperlukan oleh para pemakai laporan keuangan sebagaimana ditentukan di dalam statement of objective, (Arifin, 2003:72).

Gambaran mengenai kinerja bank syariah biasanya tercermin dalam laporan keuangannya. Laporan keuangan menunjukkan kondisi keuangan bank secara keseluruhan. Dari laporan ini akan terbaca bagaimana kondisi bank yang sesungguhnya, termasuk kelemahan dan kekuatan yang dimiliki. Laporan ini juga menunjukkan kriteria manajemen bank salama satu periode. Keuntungan dengan membaca laporan ini pihak manajemen dapat memperbaiki kelemahan yang ada serta mempertahankan kekuatan yang dimilikinya. Dalam laporan keuangan mengenai jumlah kekayaan (assets) dan jenis-jenis kekayaan yang dimiliki (disisi aktiva). Kewajiban jangka pendek maupun jangka panjang serta ekuitas yang dimilikinya juga akan terlihat. Kemudian laporan keuangan juga mengaambarkan hasil-hasil usaha yang diperoleh bank pada waktu tertentu, serta biaya atau beban yang dikeluarkan untuk memperoleh hasil tersebut

Pembuatan masing-masing laporan keuangan memiliki tujuan tersendiri. Secara umum tujuan pembuatan laporan keuangan adalah (Kasmir, 2004: 240)

1. Memberikan informasi keuangan tentang jumlah aktiva dan jenis aktiva yang dimiliki

2. Memberikan informasi keuangan tentang jumlah kewajiban dan jenis kewajiban baik jangka pendek maupun jangka panjang

3. Memberikan informasi keuangan tentang jumlah modaldan jenis modal bank pada waktu tertentu

4. Memberikan informasi tentang hasil usaha yang tercermin dari jumlah pendapatan yang diperoleh dari sumber-sumber pendapatan bank tersebut.

5. Memberikan informasi keuangan tentang jumlah biaya-biaya yang dikeluarkan berikut jenis biaya yang dikeluarkan pada periode tertentu

6. Memberikan informasi tentang perubahan-perubahan yang terjadi dalam aktiva, kewajiban dan modal suatu bank

7. Memberikan informasi tentang kinerja manajemen dalam suatu periode 
Laporan keuangan bertujuan untuk menyediakan informasi yang bermanfaat bagi pihak-pihak yang berkepentingan dalam pengambilan keputusan ekonomi yang rasional, seperti:

1. Shahibul maal/ pemilik dana

2. Pihak-pihak yang memanfaatkan dan menerima penyaluran dana

3. Pembayar zakat, infaq dan shadaqah

4. Pemegang saham

5. Otoritas pengawasan

6. Bank Indonesia

7. Pemerintah

8. Lembaga penjamin simpanan

9. Masyarakat (Pedoman Akuntansi Perbankan Syariah Indonesia, 2003)

\section{Analisis Laporan Keuangan Bank}

Analisis laporan keuangan merupakan hubungan antara suatu angka dalam laporan keuangan dengan angka lain yang mempunyai makna atau dapat menjelaskan ke arah perubahan (Soemarsono, 1992).

Rasio Likuiditas:

Analisis rasio likuiditas adalah analisis yang dilakukan terhadap kemampuan bank dalam memenuhi kewajiban-kewajiban jangka pendeknya (Santoso, 1995:91).

Kemampuan untuk membayar utang jangka pendek dari suatu perusahaan diukur dari kemampuannya untuk mendapatkan kas atau kemampuannya untuk mengkonversikan aktiva non kas menjadi kas. Dalam menganalisis likuiditas atatu bank digunakan beberapa rasio antara lain cash ratio, reserve requipment, loan to deposite ratio, dan loan to assets ratio (Dandawijaya, 2000:116).

\section{Cash Ratio}

Cash ratio adalah rasio alat liquid terhadap dana pihak ketiga yang dihimpun bank yang harus segera dibayar (Dandawijaya, 2000:116). Rasio ini digunakan untuk mengukur kemampuan bank dalam membayar kembali simpanan nasabah saat ditarik dengan menggunakan alat liquid yang dimilikinya. Perhitungan cash ratio dapat dilihat dalam rumus berikut:

$$
\begin{gathered}
\text { Alat Liquid } \\
\text { Cash ratio }= \\
\text { Pinjaman yang harus segera dibayar }
\end{gathered}
$$


Alat liquid adalah aktiva yang dapat digunakan setiap saat untuk memenuhi likuiditas bank. Aktiva ini merupakan aktiva yang paling liquid dari keseluruhan aktiva bank (Dandawijaya, 2000:68). Pengertian alat liquid dalam rasio ini terdiri atas dua hal sebagai berikut:

Kas, terdiri atas uang kertas dan uang logam yang dikeluarkan oleh Bank Indonesia Giro pada Bank Indonesia. Pos ini adalah giro milik bank pelapor pada Bank Indonesia. Jumlah tersebut tidak boleh dikurangi dengan kredit yang diberikan oleh Bank Indonesia dan tidak boleh ditambah dengan fasilitas kredit yang sudah disetujui Bank Indonesia tapi belum digunakan. (Dandawijaya, 2000:117).

\section{Reserve Requirement}

Reserve requirement atau lebih dikenal dengan likuiditas wajib minimum adalah suatu simpanan minimum yang wajib dipelihara dalam bentuk giro di bank Indonesia. Berdasarkan Surat Edaran Bank Indonesia No. 23717/BPPP tanggal 28 Februari 1992, besarnya reserve requirement adalah sebesar $2 \%$ Mulai tanggal 1 Februari 1990, besarnya RR adalah sebesar $3 \%$ dan sejak tahun 1997 menjadi $5 \%$. Besarnya Reserve Requirement dapat dilihat pada perbandingan berikut:

$$
\text { Reserve requirement }=\frac{\text { Jumlah alat likuid }}{\text { Jumlah simpanan pihak ketiga }} \text { x 100\% }
$$

Pengertian jumlah alat liquid disini sama dengan pengertian alat liquid pada perhitungan cash ratio yaitu merupakan penjumlahan dari rekening kas dan Giro pada Bank Indonesia. Sedangkan komponen dana pihak ketiga terdiri atas giro, deposito berjangka, sertifikat deposito, tabungan dan kewajiban jangka pendek lainnya (Dandawijaya, 2000; 117). Tidak ada standart untuk menentukan baik tidaknya cash ratio suatu bank. Namun bisa dikatakan bahwa semakin besar cash ratio maka bank semakin likuid.

\section{Loan to Deposito Ratio}

Loan to Deposito Ratio (LDR) pada dasarnya dapat diartikan sebagai suatu indikator untuk mengukur atau membandingkan dua komponen neraca, yaitu pinjaman (loans) yang diberikan di sisi aktiva dan dana yang diterima oleh bank di sisi pasiva. LDR adalah rasio antara seluruh jumlah kredit yang diberikan oleh bank dengan dana yang diterima oleh bank (Dandawijaya, 2000'1 18). LDR dapat dihitung dengan menggunakan rumus:

Jumlah kredit yang diberikan

$$
L D R=\text { Dana pihak ketiga }+ \text { KLBI + Modal inti }
$$


Jumlah kredit yang diberikan dalam rumus diatas adalah kredit yang diberikan bank yang sudah direalisir/ditarik/dicairkan. Dana pihak ketiga meliputi simpanan masyarakat yang berbentuk giro, tabungan dan berbagai jenis deposito, sedangkan KLBI adalah volume pemberian pinjaman (kredit) yang diberikan Bank Indonesia kepada bank yang bersangkutan. Rasio ini merupakan suatu indikator kerawanan dan kemampuan suatu bank. Sebagian praktisi perbankan menyepakati bahwa batas aman dari LDR suatu bank adalah sekitar 80\%. Namun, batas toleransinya sekitar 85\%-100\%. (Dardawijaya, 2000:119)

\section{Loan to Assets Ratio}

Loan to assets ratio adalah rasio yang digunakan untuk mengukur tingkat likuiditas bank yang menunjukkan kemampuan bank untuk memenuhi permintaan kredit dengan menggunakan total asset yang dimiliki bank. Dengan kata lain, rasio ini merupakan perbandingan seberapa besar kredit yang diberikan bak dibandingkan dengan besarnya total assets yang dimiliki oleh bank. Rasio ini dapat dirumuskan sebagai berikut:

Loan to assets ratio = - $\begin{gathered}\text { Jumlah kredit yang diberikan } \\ \text { Jumlah assets }\end{gathered}$

(Dandawijaya, 2000:119). Semakin kecil Loan To Assets Ratio maka bank dianggap semakin liquid. Hal ini disebabkan karena kemampuannya untuk memenuhi permintaan kredit dengan menggunakan total asset yang dimilikinya juga semakin besar.

\section{BAB III . METODE PENELITIAN}

Metode merupakan cara yang dipakai untuk mencapai tujuan. Sedangkan metode penelitian merupakan tata cara bagaimana suatu penelitian dilaksanakan. Metode penelitian ini digunakan sebagai pemandu bagaimana penelitian dilakukan sehingga diperoleh jawaban-jawaban yang sesuai atas permasalahan yang diangkat serta diperoleh kesimpulan- kesimpulan yang tidak meragukan

\section{A. Rancangan Penelitian}

Dalam penelitian ini digunakan jenis penelitian deskriptif, yaitu suatu penelitian yang bertujuan untuk memberikan gambaran atau lukisan secara sistematis, faktual dan akurat mengenai fenomena atau hubungan antara fenomena yang diselidiki. Metode deskriptif ini menekankan gambaran obyek yang diselidiki dalam keadaan sekarang (Imam dan Tabroni, 2001:137). Sedangkan menurut Iqbal Hasan (2002:21), penelitian deskriptif artinya penelitian yang melukiskan variabel demi variabel, satu demi satu. Metode ini 
digunakan untuk melukiskan secara sistematis fakta atau karakteristik populasi tertentu atau bidang tertentu.

\section{B. Variabel dan Pengukurannya}

Variabel dalam penelitian ini adalah rasio likuiditas. Likuiditas adalah analisis yang dilakukan terhadap kemampuan bank dalam memenuhi kewajiban-kewajiban jangka pendeknya. Variabel ini diukur dengan menggunakan analisa terhadap rasio-rasio yaitu:

1. Cash Ratio, adalah rasio alat liquid terhadap dana pihak ketiga yang dihimpun bank yang harus segera dibayar selama 1 tahun yang dinyatakan dalam persen.

2. Reserve Requirement adalah suatu simpanan wajib minimum yang wajib dipelihara oleh bank di Bank Indonesia selama 1 tahun yang dinyatakan dalam persen.

3. Loan To Deposite Ratio adalah rasio antara seluruh jumlah kredit yang diberikan oleh bank dengan dana yang diterima oleh bank selama 1 tahun yang dinyatakan dalam persen.

4. Loan to Assets Ratio adalah rasio yang digunakan untuk mengukur tingkat likuiditas bank yang menunjukkan kemampuan bank untuk memenuhi permintaan kredit dengan menggunakan total asset yang dimiliki bank selama 1 tahun yang dinyatakan dalam persen

\section{Pengumpulan Data}

Dikarenakan penilaian kinerja keuangan bank ini bersifat riskan bagi bank, maka penelitian tidak dapat dilakukan pada bank yang bersangkutan, sehingga penelitian ini dilakukan di Kantor Bank Indonesia cabang Malang, dengan data laporan keuangan tahunan yang bersangkutan yang diserahkan pada Bank Indonesia. Dalam penelitian ini digunakan jenis data sekunder. Data sekunder merupakan data yang diperoleh peneliti secara tidak langsung melalui media perantara (diperoleh dan dicatat oleh pihak lain). Data sekunder ini meliputi dokumen-dokumen, bukti, catatan-catatan atau laporan historis resmi perusahaan dan tulisan-tulisan lain yang relevan dengan fokus penelitian ini. Sedangkan metode pengumpulan data yang digunakan adalah metode dokumentasi. Metode dokumentasi merupakan usaha mengumpulkan data yang dilakukan dengan jalan mencari data yang berapa laporan keuangan, surat kabar, majalah, dan dokumen penunjang lainnya. 
Dalam hal ini data yang dikumpulkan dengan menggunakan teknik dokumentasi adalah laporan kuantitatif dari bank yang bersangkutan.

\section{Metode Analisis}

Tujuan analisis dalam penelitian adalah untuk menyempitkan dan membatasi penemuan-penemuan hingga menjadi suatu data yang teratur, tersusun dan lebih berarti (Marzuki, 2000.87). Dalam penelitian ini menggunakan analisis time series (Time Series Analysis), dimana analisa tersebut dilakukan dengan membandingkan data yang didapatkan oleh peneliti dari tahun 2001 sampai dengan 2004. Teknik analisis yang digunakan adalah analisis rasio keuangan perbankan yang meliputi :

\section{Cash Ratio}

Dapat dihitung dengan menggunakan rumus :

$$
\begin{gathered}
\text { Alat likuid } \\
\text { Cash ratio }= \\
\text {--------------------------------- x 100\% }
\end{gathered}
$$

2. Reserve Requipment (RR)

Dapat dihitung dengan menggunakan rumus :

$$
\begin{aligned}
& \text { Jumlah Alat likuid } \\
& \text { Reserve Requirement = ---------------------- } \text { x 100\% } \\
& \text { 3. Loan to Deposite Ratio (LDR) } \\
& \text { Jumlah Pinjaman Pihak Ketiga }
\end{aligned}
$$

Dapat dihitung dengan menggunakan rumus :

$$
\text { Loan to Deposit Ratio }=\frac{\text { Jumlah Kredit Yang Diberikan }}{\text { Dana Pihak Ketiga+ KLBI+Modal Inti }}
$$

4. Loan to Assets Ratio (LAR)

Dapat dihitung dengan menggunakan rumus :

Loan to Assets Ratio = - $\begin{gathered}\text { Jumlah Kredit Yang Diberikan } \\ \text { Jumlah Assets }\end{gathered}$

\section{BAB IV. HASIL PENELITIAN}

\section{Deskripsi Data dan Analisa Data}

\section{Aspek Likuiditas}

a. Cash Ratio 
Rata-rata industri kemampuan bank dalam memenuhi kewajiban jangka pendeknya dilihat dari perbandingan aktiva yang dapat digunakan setiap saat utuk memenuhi likuiditas bank (alat likuid) terhadap dana pihak ketiga yang dihimpun bank yang harus segera dibayar pada tahun 20001 adalah 100,8\%. Kemampuan Bank Mandiri Syariah dalam cash rasio adalah 68,53 \%. Ini berarti bahwa bank mampu menjamin setiap Rp 1 pinjaman yang harus dibayar dengan 0,68 alat likuidnya, Cash ratio Bank Muamalat Indonesia sebesar 84,92\% Ini berarti bahwa bank mampu menjamin setiap Rp 1 pinjaman yang harus dibayar dengan 0,85 alat likuidnya. Bank Syariah Mega Indonesia cash rationya sebesar $149,7 \%$. Ini berarti bahwa bank mampu menjamin setiap Rp 1 pinjaman yang harus dibayar dengan 1,49 alat likuidnya,

Tabel 3. Cash Ratio Rata-rata Industri

Tahun 2001 s.d. 2004

(Dalam Jutaan Rupiah)

\begin{tabular}{|l|r|r|r|r|}
\hline \multicolumn{1}{|c|}{ Keterangan } & Tahun 2001 & \multicolumn{1}{c|}{ Tahun 2002 } & Tahun 2003 & \multicolumn{1}{c|}{ Tahun 2004 } \\
\hline Cash ratio Bank Mandiri Syariah & 68.53 & 60.98 & 82.68 & 50.3 \\
\hline $\begin{array}{l}\text { Cash ratio Bank Muamalat } \\
\text { Indonesia }\end{array}$ & 84.92 & 68.69 & 87.41 & 73.38 \\
\hline $\begin{array}{l}\text { Cash ratio Bank Syariah Mega } \\
\text { Indonesia }\end{array}$ & 149.2 & 224.47 & 66.496 & 267.25 \\
\hline Total cash ratio & 302.65 & 354.14 & 236.586 & 390.93 \\
\hline Cash Ratio Rata-Rata Industri & $\mathbf{1 0 0 . 8 8 3 3 3 3 3}$ & $\mathbf{1 1 8 . 0 4 6 6 6 6 7}$ & $\mathbf{7 8 . 8 6 2}$ & $\mathbf{1 3 0 . 3 1}$ \\
\hline
\end{tabular}

Sumber : data diolah

Sedangkan tahun 2002 cash ratio rata-rata industri adalah $118 \%$. Cash ratio

Bank Mandiri Syariah adalah 60,98 \%. Menggambarkan kemampuan bank dalam menjamin setiap Rp 1 pinjaman yang harus dibayar dengan 0,60 alat likuidnya, Cash ratio Bank Muamalat Indonesia sebesar 68,69 \% Kemampuan bank dalam menjamin setiap Rp 1 pinjaman yang harus dibayar dengan 0,69 alat likuidnya. Bank Syariah Mega Indonesia cash rationya sebesar 2,24 \%. Ini berarti bahwa bank mampu menjamin setiap $\mathrm{Rp} 1$ pinjaman yang harus dibayar dengan 2,24 alat likuidnya, Dari ketiga bank dapat dilihat bahwa kemampuan cash ratio Bank Syariah Mega Indonesia adalah yang tertinggi. Disusul oleh Bank Muamalat Indonesia di peringkat kedua. Dan yang terakhir adalah Bank Mandiri Syariah. Hal ini mencerminkan bahwa semakin besar cash ratio, maka kemampuan bank dalam membayar kewajiban jangka pendeknya dengan alat likuid yang dimilikinya semakin terjamin

Pada tahun 2003 cash ratio rata-rata industri adalah mengalami penurunan, yaitu 78,86\%. Cash ratio Bank Mandiri Syariah adalah 82,68 \%. Ini berarti bahwa bank mampu menjamin setiap Rp 1 pinjaman yang harus dibayar dengan 0,83 alat likuidnya, Cash ratio Bank Muamalat Indonesia sebesar 87,41 \% Ini berarti bahwa bank mampu menjamin 
setiap Rp 1 pinjaman yang harus dibayar dengan 0,87 alat likuidnya. Bank Syariah Mega Indonesia cash rationya sebesar 66,5 \%. Ini berarti bahwa bank mampu menjamin setiap Rp 1 pinjaman yang harus dibayar dengan 0,66 alat likuidnya, Dari ketiga bank Kemampuan cash ratio terbesar adalah Bank Muamalat Indonesia, disusul oleh Bank Mandiri Syariah. Dan yang terakhir adalah Bank Syariah Mega Indonesia.

Kemampuan cash ratio rata-rata industri pada tahun 2004 mengalami peningkatan, yaitu 130,31 \%. Cash ratio Bank Mandiri Syariah adalah 50,3\%. Menggambarkan kemampuan bank dalam menjamin setiap Rp 1 pinjaman yang harus dibayar dengan 0,50 alat likuidnya, Cash ratio Bank Muamalat Indonesia sebesar 73,38 \% Kemampuan bank dalam menjamin setiap Rp 1 pinjaman yang harus dibayar dengan 0,73 alat likuidnya. Bank Syariah Mega Indonesia cash rationya sebesar 267,93 \%. Ini berarti bahwa bank mampu menjamin setiap Rp 1 pinjaman yang harus dibayar dengan 2,67 alat likuidnya, Dari ketiga bank dapat dilihat bahwa kemampuan cash ratio Bank Syariah Mega Indonesia adalah yang tertinggi. Disusul oleh Bank Muamalat Indonesia di peringkat kedua. Dan yang terakhir adalah Bank Mandiri Syariah. Hal ini mencerminkan bahwa semakin besar cash ratio, maka kemampuan bank dalam membayar kewajiban jangka pendeknya dengan alat likuid yang dimilikinya semakin terjamin Cash ratio Bank Mandiri Syariah adalah 60,98 \%. Menggambarkan kemampuan bank dalam menjamin setiap Rp 1 pinjaman yang harus dibayar dengan 0,60 alat likuidnya, Cash ratio Bank Muamalat Indonesia sebesar 68,69 \% Kemampuan bank dalam menjamin setiap Rp 1 pinjaman yang harus dibayar dengan 0,69 alat likuidnya. Bank Syariah Mega Indonesia cash rationya sebesar $2,24 \%$. Ini berarti bahwa bank mampu menjamin setiap Rp 1 pinjaman yang harus dibayar dengan 2,24 alat likuidnya, Dari ketiga bank dapat dilihat bahwa kemampuan cash ratio Bank Syariah Mega Indonesia adalah yang tertinggi. Disusul oleh Bank Muamalat Indonesia di peringkat kedua. Dan yang terakhir adalah Bank Mandiri Syariah. Hal ini mencerminkan bahwa semakin besar cash ratio, maka kemampuan bank dalam membayar kewajiban jangka pendeknya dengan alat likuid yang dimilikinya semakin terjamin Kemampuan Bank Mandiri Syariah dalam cash rasio adalah $68,53 \%$. Ini berarti bahwa bank mampu menjamin setiap Rp 1 pinjaman yang harus dibayar dengan 0,68 alat likuidnya, Cash ratio Bank Muamalat Indonesia sebesar 84,92\% Ini berarti bahwa bank mampu menjamin setiap Rp 1 pinjaman yang harus dibayar dengan 0,85 alat likuidnya. Bank Syariah Mega Indonesia cash rationya sebesar 149,7\%. Ini berarti bahwa bank mampu menjamin setiap Rp 1 pinjaman yang harus dibayar dengan 1,49 alat likuidnya, Dari ketiga bank dapat dilihat bahwa kemampuan cash ratio Bank 
Syariah Mega Indonesia adalah yang tertinggi. Disususl oleh Bank Muamalat Indonesia di peringkat kedua. Dan yang terakhir adalah Bank Mandiri Syariah. Hal ini mencerminkan bahwa semakin besar cash ratio, maka bank semakin likuid.

\section{b. Reserve Requipment :}

Likuiditas wajib minimum atau simpanan wajib dipelihara dalam bentuk giro di Bank Indonesia (reserve requipment) rata-rata industri pada tahun 2001 sebesar 8,161\%. Kemampuan simpanan wajib minimum yang wajib dipelihara oleh Bank Indonesia selama 1 tahun (reserve requipment). Bank Syariah Mandiri sebesar 8,613 \%. Untuk Bank Muamalat sebesar 10,661\%. Sedangkan untuk Bank Syariah Mega Indonesia sebesar $24,484 \%$.

Tabel 13. Reserve Requirement Rata-rata Industri

Tahun 2001 s.d. 2004

(dalam jutaan rupiah)

\begin{tabular}{|l|r|r|r|r|}
\hline \multicolumn{1}{|c|}{ Keterangan } & Tahun 2001 & Tahun 2002 & Tahun 2003 & Tahun 2004 \\
\hline $\begin{array}{l}\text { Reserve Requirement Bank Mandiri } \\
\text { Syariah }\end{array}$ & 8.613 & 7.2 & 10.89 & 8.18 \\
\hline $\begin{array}{l}\text { Reserve Requirement Bank Muamalat } \\
\text { Indo }\end{array}$ & 10.661 & 5.46 & 8.42 & 6.47 \\
\hline $\begin{array}{l}\text { Reserve Requirement Bank Syariah } \\
\text { Mega Indo }\end{array}$ & 5.21 & 5.63 & 6.13 & 10.01 \\
\hline Total Reserve Requirement & 24.484 & 18.29 & 25.44 & 24.66 \\
\hline $\begin{array}{l}\text { Rata-rata Industri Reserve } \\
\text { Requirement }\end{array}$ & $\mathbf{8 . 1 6 1}$ & $\mathbf{6 . 0 9 7}$ & $\mathbf{8 . 4 8 0}$ & $\mathbf{8 . 2 2 0}$ \\
\hline
\end{tabular}

Sumber : data diolah

Rata-rata industri kemampuan simpanan wajib minimum yang wajib dipelihara oleh Bank Indonesia pada tahun 2002 mengalami penurunan yaitu sebesar 6,097\%. Sedangkan reserve requipment Bank Syariah Mandiri sebesar 7,2\%, Bank Muamalat Indonesia sebesar 5,46 \% dan Bank Syariah Mega Indonesia sebesar 5,63\%.Pada tahun 2003 reserve requipment rata-rata industri mengalami peningkatan, yaitu 8,480\%. Kemampuan reserve requipment Bank Syariah Mandiri mengalami peningkatan, yaitu 10,89\%. Bank Muamalat Indonesia besarnya reserve requipment adalah 8,42\%. Sedangkan Bank Syariah Mega Indonesia sebesar 6,13\%.

Kemampuan rata-rata industri dalam simpanan wajib minimum yang harus dipelihara oleh Bank Indonesia pada tahun 2004 sebesar 8, 220\%. Kemampuan dari bank Syariah Mandiri sebesar 8,18\%, Bank Muamalat Indonesia sebesar 6,47\% dan Bank Syariah Mega Indonesia sebesar 10,01\%.

\section{c. Loan to Deposite Ratio}


Indikator yang digunakan untuk mengukur atau membandingkan dua komponen neraca, yaitu pinjaman yang diberikan di sisi aktiva dan dana yang diterima oleh bank, rata-rata industri pada tahun 2001 sebesar 75,48\%. Pada tahun 2001 kemampuan loan to deposite ratio Bank Syariah Mandiri sebesar 76,197\%. Bank Muamalat Indonesia sebesar 77,680\%. Sedangkan Bank syariah Mega Indonesia sebesar 72,570 \%. Rata-rata industri loan to deposite ratio pada tahun 2002 sebesar 77,673\%. Kemampuan dari bank Syariah Mandiri sebesar 74,560\%. bank Muamalat Indonesia sebesar 86,540\%. Sedangkan bank Syariah Mega Indonesia sebesar 71,920\%.

Tabel 24. Perhitungan Loan to Deposite Ratio Rata-rata Industri

Tahun 2001 s.d. 2004

(dalam jutaan rupiah)

\begin{tabular}{|l|r|r|r|r|}
\hline \multicolumn{1}{|c|}{ Keterangan } & Tahun 2001 & Tahun 2002 & Tahun 2003 & \multicolumn{1}{c|}{ Tahun 2004 } \\
\hline LDR Bank Mandiri sy ariah & 76.197 & 74.560 & 70.680 & 85.160 \\
\hline LDR Bank Muamalat Indonesia & 77.680 & 86.540 & 71.720 & 80.280 \\
\hline LDR Bank Sy ariah Mega Indonesia & 72.570 & 71.920 & 96.370 & 70.000 \\
\hline Total LDR & 226.447 & 233.020 & 238.770 & 235.440 \\
\hline Rata-Rata LD & $\mathbf{7 5 . 4 8 2}$ & $\mathbf{7 7 . 6 7 3}$ & $\mathbf{7 9 . 5 9 0}$ & $\mathbf{7 8 . 4 8 0}$ \\
\hline
\end{tabular}

Sumber : data diolah

Kemampuan loan to deposite rata-rata industri pada tahun 2003 sebesar 79,590\%. Kemampuan ini mengalami peningkatan, namun kemampuan loan to deposite untuk bank Syariah Mandiri serta bank Syariah Mega Indonesia mengalami penurunan. penurunan yang dialami bank Syariah Mandiri sebesar yaitu 1,637\%. Sedangkan bank Syariah Mega Indonesia sebesar $0,65 \%$. Bank Muamalat Indonesia malah mengalami peningkatan sebesar $8,86 \%$.

Pada tahun 2004 kemampuan rata-rata industri sebesar 78,480\%. Kemampuan ini mengalami penurunan sebesar $1,11 \%$. Loan to deposite untuk kedua bank, yaitu bank Syariah Mandiri dan bank Muamalat Indonesia mengalami peningkatan. Bank Syariah Mandiri mengalami peningkatan sebesar 14,48\%. Sedangkan Bank Muamalat Indonesia sebesar 8,56\%. Untuk Bank Syariah Mega Indonesia mengalami penurunan sebesar 26,37 \%. Rasio ini merupakan indikator kerawanan dan kemampuan suatu bank. Sebagian praktisi perbankan menyepakati bahwa batas aman dari loan to deposite ratio suatu bank adalah sekitar 80\%. Namun batas toleransinya sekitar 85\%-100\% (Dandawijaya,2000:119)

\section{d. Loan to Total Assets}

Kemampuan rata-rata industri untuk memenuhi permintaan kredit dengan menggunakan total asssets yang dimiliki bank (loan to asset ratio) mulai tahun 2001 s.d 
2004 mengalami peningkatan. Tahun 2001 kemampuan loan to total assets sebesar 63,4\%. Pada tahun 2002 mengalami kenaikan sebesar 8,26\%. Pada tahun 2003 loan to total asset rata-rata ind ustri sebesar 72,3\%. Dan tahun 2004 sebesar 74,99\%. Pada tahun 2002 Bank Syariah Mandiri mengalami kenaikan 0,68\%, namun pada tahun 2003 mengalami penurunan sebesar 7,2 \%. Sedangkan pada tahun 2004 meningkat 13,66\%.

Bank Muamalat Indonesia loan to assetsnya pada tahun 2001 mencapai 77,68\%. Pada tahun 2002 mengalami kenaikan sebesar 8,25\%. Namun pada tahun 2003 mengalami penurunan sebesar 14,21\%. Sedangkan pada tahun 2004 mengalami peningkatan lagi sebesar 8,56\%. Kemampuan Bank Syariah Mega Indonesia dalam memenuhi permintaan kredit dengan menggunakan total assets yang dimilikinya pada tahun 2001 sebesar 42,53\% . Rasio ini paling kecil dibanding dengan Bank Muamalat Indonesia dan Bank Syariah Mandiri. Pada tahun 2002 serta 20003 mengalami peningkatan sebesar 15,89\% dan 23,32\%. Namun pada tahun 2004 kemampuan loan to assets ratio Bank Syariah Mega Indonesia mengalami penurunan sebesar $14,12 \%$.

Tabel 35. Perhitungan Loan to Assets Rata-rata Ind ustri Tahun 2001 s.d 2004

(dalam jutaan Rp)

\begin{tabular}{|l|r|r|r|r|}
\hline \multicolumn{1}{|c|}{ Keterangan } & Tahun 2001 & Tahun 2002 & \multicolumn{1}{c|}{ Tahun 2003 } & Tahun 2004 \\
\hline L AR Bank Mandiri Syariah (\%) & 69.94 & 70.62 & 63.42 & 77.08 \\
\hline L AR Bank Muamalat Indonesia (\%) & 77.68 & 85.93 & 71.72 & 80.28 \\
\hline L AR Bank Syariah Mega Indonesia (\%) & 42.53 & 58.42 & 81.74 & 67.62 \\
\hline Total LAR & 190.15 & 214.97 & 216.88 & 224.98 \\
\hline L AR Rata-Rata (\%) & $\mathbf{6 3 . 3 8 3 3 3 3 3 3}$ & $\mathbf{7 1 . 6 5 6 6 6 6 6 7}$ & $\mathbf{7 2 . 2 9 3 3 3 3 3 3}$ & $\mathbf{7 4 . 9 9 3 3 3 3 3 3}$ \\
\hline
\end{tabular}

Sumber : data diolah

\section{BAB V \\ PEMBAHASAN}

\section{Aspek Likuiditas}

\section{a) Cash Ratio}

Rata-rata industri kemampuan bank dalam memenuhi kewajiban jangka pendeknya dilihat dari perbandingan aktiva yang dapat digunakan setiap saat utuk memenuhi likuiditas bank (alat likuid) terhadap dana pihak ketiga yang dihimpun bank yang harus segera dibayar pada tahun 20001 adalah 100,8\%. Kemampuan Bank Mandiri Syariah dalam cash rasio adalah 68,53 \%. Ini berarti bahwa bank mampu menjamin setiap Rp 1 pinjaman yang harus dibayar dengan 0,68 alat likuidnya, Cash ratio Bank Muamalat Indonesia sebesar 84,92\% Ini berarti bahwa bank mampu menjamin setiap Rp 1 pinjaman yang harus dibayar dengan 0,85 alat likuidnya. Bank Syariah Mega Indonesia cash rationya sebesar $149,7 \%$. Ini berarti bahwa bank mampu menjamin setiap Rp 1 pinjaman 
yang harus dibayar dengan 1,49 alat likuidnya, Dari ketiga bank dapat dilihat bahwa kemampuan cash ratio Bank Syariah Mega Indonesia adalah yang tertinggi. Disusul oleh Bank Muamalat Indonesia di peringkat kedua. Dan yang terakhir adalah Bank Mandiri Syariah. Hal ini mencerminkan bahwa semakin besar cash ratio, maka bank semakin likuid.

Sedangkan tahun 2002 cash ratio rata-rata industri adalah $118 \%$. Cash ratio Bank Mandiri Syariah adalah 60,98 \%. Menggambarkan kemampuan bank dalam menjamin setiap Rp 1 pinjaman yang harus dibayar dengan 0,60 alat likuidnya, Cash ratio Bank Muamalat Indonesia sebesar 68,69 \% Kemampuan bank dalam menjamin setiap Rp 1 pinjaman yang harus dibayar dengan 0,69 alat likuidnya. Bank Syariah Mega Indonesia cash rationya sebesar $2,24 \%$. Ini berarti bahwa bank mampu menjamin setiap Rp 1 pinjaman yang harus dibayar dengan 2,24 alat likuidnya, Dari ketiga bank dapat dilihat bahwa kemampuan cash ratio Bank Syariah Mega Indonesia adalah yang tertinggi. Disusul oleh Bank Muamalat Indonesia di peringkat kedua. Dan yang terakhir adalah Bank Mandiri Syariah. Hal ini mencerminkan bahwa semakin besar cash ratio, maka kemampuan bank dalam membayar kewajiban jangka pendeknya dengan alat likuid yang dimilikinya semakin terjamin

Pada tahun 2003 cash ratio rata-rata industri adalah mengalami penurunan, yaitu 78,86\%. Cash ratio Bank Mandiri Syariah adalah 82,68 \%. Ini berarti bahwa bank mampu menjamin setiap Rp 1 pinjaman yang harus dibayar dengan 0,83 alat likuidnya, Cash ratio Bank Muamalat Indonesia sebesar 87,41 \% Ini berarti bahwa bank mampu menjamin setiap Rp 1 pinjaman yang harus dibayar dengan 0,87 alat likuidnya. Bank Syariah Mega Indonesia cash rationya sebesar 66,5\%. Ini berarti bahwa bank mampu menjamin setiap Rp 1 pinjaman yang harus dibayar dengan 0,66 alat likuidnya, Dari ketiga bank Kemampuan cash ratio terbesar adalah Bank Muamalat Indonesia, disusul oleh Bank Mandiri Syariah. Dan yang terakhir adalah Bank Syariah Mega Indonesia.

Kemampuan cash ratio rata-rata ind ustri pada tahun 2004 mengalami peningkatan, yaitu 130,31 \%. Cash ratio Bank Mandiri Syariah adalah 50,3 \%. Menggambarkan kemampuan bank dalam menjamin setiap Rp 1 pinjaman yang harus dibayar dengan 0,50 alat likuidnya, Cash ratio Bank Muamalat Indonesia sebesar 73,38 \% Kemampuan bank dalam menjamin setiap Rp 1 pinjaman yang harus dibayar dengan 0,73 alat likuidnya. Bank Syariah Mega Indonesia cash rationya sebesar 267,93 \%. Ini berarti bahwa bank mampu menjamin setiap Rp 1 pinjaman yang harus dibayar dengan 2,67 alat likuidnya, Dari ketiga bank dapat dilihat bahwa kemampuan cash ratio Bank Syariah Mega Indonesia 
adalah yang tertinggi. Disusul oleh Bank Muamalat Indonesia di peringkat kedua. Dan yang terakhir adalah Bank Mandiri Syariah. Hal ini mencerminkan bahwa semakin besar cash ratio, maka kemampuan bank dalam membayar kewajiban jangka pendeknya dengan alat likuid yang dimilikinya semakin terjamin Cash ratio Bank Mandiri Syariah adalah 60,98 \%. Menggambarkan kemampuan bank dalam menjamin setiap Rp 1 pinjaman yang harus dibayar dengan 0,60 alat likuidnya, Cash ratio Bank Muamalat Indonesia sebesar 68,69 \% Kemampuan bank dalam menjamin setiap Rp 1 pinjaman yang harus dibayar dengan 0,69 alat likuidnya. Bank Syariah Mega Indonesia cash rationya sebesar 2,24 \%. Ini berarti bahwa bank mampu menjamin setiap Rp 1 pinjaman yang harus dibayar dengan 2,24 alat likuidnya, Dari ketiga bank dapat dilihat bahwa kemampuan cash ratio Bank Syariah Mega Indonesia adalah yang tertinggi. Disusul oleh Bank Muamalat Indonesia di peringkat kedua. Dan yang terakhir adalah Bank Mandiri Syariah. Hal ini mencerminkan bahwa semakin besar cash ratio, maka kemampuan bank dalam membayar kewajiban jangka pendeknya dengan alat likuid yang dimilikinya semakin terjamin Kemampuan Bank Mandiri Syariah dalam cash rasio adalah 68,53 \%. Ini berarti bahwa bank mampu menjamin setiap Rp 1 pinjaman yang harus dibayar dengan 0,68 alat likuidnya, Cash ratio Bank Muamalat Indonesia sebesar 84,92\% Ini berarti bahwa bank mampu menjamin setiap Rp 1 pinjaman yang harus dibayar dengan 0,85 alat likuidnya. Bank Syariah Mega Indonesia cash rationya sebesar $149,7 \%$. Ini berarti bahwa bank mampu menjamin setiap Rp 1 pinjaman yang harus dibayar dengan 1,49 alat likuidnya, Dari ketiga bank dapat dilihat bahwa kemampuan cash ratio Bank Syariah Mega Indonesia adalah yang tertinggi. Disususl oleh Bank Muamalat Indonesia di peringkat kedua. Dan yang terakhir adalah Bank Mandiri Syariah. Hal ini mencerminkan bahwa semakin besar cash ratio, maka bank semakin likuid.

\section{b) Reserve Requipment :}

Likuiditas wajib minimum atau simpanan wajib dipelihara dalam bentuk giro di Bank Indonesia (reserve requipment) rata-rata industri pada tahun 2001 sebesar 8,161\%. Kemampuan simpanan wajib minimum yang wajib dipelihara oleh Bank Indonesia selama 1 tahun (reserve requipment). Bank Syariah Mandiri sebesar 8,613 \%. Untuk Bank Muamalat sebesar 10,661\%. Sedangkan untuk Bank Syariah Mega Indonesia sebesar $24,484 \%$.

Rata-rata industri kemampuan simpanan wajib minimum yang wajib dipelihara oleh Bank Indonesia pada tahun 2002 mengalami penurunan yaitu sebesar 6,097\%. 
Sedangkan reserve requipment Bank Syariah Mandiri sebesar 7,2\%,Bank Muamalat Indonesia sebesar 5,46 \% dan Bank Syariah Mega Indonesia sebesar 5,63\%.

Pada tahun 2003 reserve requipment rata-rata industri mengalami peningkatan , yaitu 8,480\%. Kemampuan reserve requipment Bank Syariah Mandiri mengalami peningkatan, yaitu 10,89\%. Bank Muamalat Indonesia besarnya reserve requipment adalah 8,42\%. Sedangkan Bank Syariah Mega Indonesia sebesar 6,13\%. Kemampuan ratarata industri dalam simpanan wajib minimum yang harus dipelihara oleh Bank Indonesia pada tahun 2004 sebesar 8, 220\%. Kemampuan dari bank Syariah Mandiri sebesar 8,18\%, Bank Muamalat Indonesia sebesar 6,47\% dan Bank Syariah Mega Indonesia sebesar $10,01 \%$.

Berdasarkan ketentuan Surat Edaran Bank Indonesia No 23/17/BPPP tanggal 28 Februari 1992, besarnya reserve requipment adalah sebesar $2 \%$. Namun peraturan itu sudah mengalami perubahan, yakni tertanggal 1 Februari 1996 besarnya reserve requipment adalah $3 \%$. Namun sejak tahun 1997 besarnya reserve requipment menjadi 5 $\%$. Secara umum reserve requipment ketiga bank tersebut diatas $5 \%$. Namun pada tahun 2002 secara umum reserve requipment ketiga bank mengalami penurunan, namun masih diatas ambang batas $5 \%$.

\section{c) Loan to Assets Deposite Ratio}

Indikator yang digunakan untuk mengukur atau membandingkan dua komponen neraca, yaitu pinjaman yang diberikan di sisi aktiva dan dana yang diterima oleh bank, rata-rata industri pada tahun 2001 sebesar 75,48\%. Pada tahun 2001 kemampuan loan to deposite ratio Bank Syariah Mandiri sebesar 76,197\%. Bank Muamalat Indonesia sebesar 77,680\%. Sedangkan Bank syariah Mega Indonesia sebesar 72,570 \%.

Rata-rata industri loan to deposite ratio pada tahun 2002 sebesar 77,673\%. Kemampuan dari bank Syariah Mandiri sebesar 74,560 \%. bank Muamalat Indonesia sebesar 86,540\%. Sedangkan bank Syariah Mega Indonesia sebesar 71,920\%. Kemampuan loan to deposite rata-rata industri pada tahun 2003 sebesar 79,590\%. Kemampuan ini mengalami peningkatan, namun kemampuan loan to deposite untuk bank Syariah Mandiri serta bank Syariah Mega Indonesia mengalami penurunan. penurunan yang dialami bank Syariah Mandiri sebesar yaitu 1,637\%. Sedangkan bank Syariah Mega Indonesia sebesar 0,65\%. Bank Muamalat Indonesia malah mengalami peningkatan sebesar 8,86\%.

Pada tahun 2004 kemampuan rata-rata industri sebesar 78,480\%. Kemampuan ini mengalami penurunan sebesar $1,11 \%$. Loan to deposite untuk kedua bank, yaitu bank Syariah Mandiri dan bank Muamalat Indonesia mengalami peningkatan. Bank Syariah 
Mandiri mengalami peningkatan sebesar 14,48\%. Sedangkan Bank Muamalat Indonesia sebesar 8,56 \%. Untuk Bank Syariah Mega Indonesia mengalami penurunan sebesar 26,37 \%. Rasio ini merupakan indikator kerawanan dan kemampuan suatu bank. Sebagian praktisi perbankan menyepakati bahwa batas aman dari loan to deposite ratio suatu bank adalah sekitar 80\%. Namun batas toleransinya sekitar 85\%-100\% (Dandawijaya,2000:119)

\section{d) Loan to Total Assets}

Kemampuan rata-rata industri untuk memenuhi permintaan kredit dengan menggunakan total asssets yang dimiliki bank (loan to asset ratio) mulai tahun 2001 s.d 2004 mengalami peningkatan. Tahun 2001 kemampuan loan to total assets sebesar 63,4\%. Pada tahun 2002 mengalami kenaikan sebesar 8,26\%. Pada tahun 2003 loan to total asset rata-rata ind ustri sebesar 72,3\%. Dan tahun 2004 sebesar 74,99\%. Pada tahun 2002 Bank Syariah Mandiri mengalami kenaikan 0,68\%, namun pada tahun 2003 mengalami penurunan sebesar 7,2\%. Sedangkan pada tahun 2004 meningkat 13,66\%.

Bank Muamalat Indonesia loan to assetsnya pada tahun 2001 mencapai 77,68\%. Pada tahun 2002 mengalami kenaikan sebesar 8,25\%. Namun pada tahun 2003 mengalami penurunan sebesar 14,21\%. Sedangkan pada tahun 2004 mengalami peningkatan lagi sebesar 8,56\%. Kemampuan Bank Syariah Mega Indonesia dalam memenuhi permintaan kredit dengan menggunakan total assets yang dimilikinya pada tahun 2001 sebesar 42,53\% . Rasio ini paling kecil dibanding dengan Bank Muamalat Indonesia dan Bank Syariah Mandiri. Pada tahun 2002 serta 20003 mengalami peningkatan sebesar 15,89\% dan 23,32\%. Namun pada tahun 2004 kemampuan loan to assets ratio Bank Syariah Mega Indonesia mengalami penurunan sebesar $14,12 \%$.

Rata-rata cash ratio industri tahun 2001, tahun 2002 serta tahun 2004 terus mengalami peningkatan. Peningkatan cash ratio rata-rata industri perbankan syariah mencerminkan kemampuan rata-rata perbankan syariah dalam membayar simpanan nasabah dengan alat likuid yang dimiliki terus meningkat. Selama tahun 2001 dan tahun 2002 serta tahun 2004 cash ratio perbankan syariah yang diatas rata-rata adalah Bank Mega Syariah Indonesia. Sedangkan pada tahun 2003 bank Mandiri Syariah dan bank Muamalat Indonesia menghasilkan cash ratio diatas rata-rata. Hal tersebut terjadi karena adanya peningkatan alat likuid khususnya giro pada bank Indone sia. Nilai cash ratio yang semakin besar mencerminkan kondisi bank tersebut semakin likuid. Kecuali tahun 2003 cash ratio rata-rata industri mengalami penurunan. Hal ini disebabkan oleh penurunan cah ratio dari bank Syariah Mega Indonesia. Penurunan cash ratio bank Syariah Mega 
Indonesia disebabkan karena meningkatnya komposisi jumlah pinjaman yang harus segera dibayar, terutama dalam bentuk giro.

Dilihat dari kemampuan perbankan syariah dalam memenuhi Giro Wajib Minimum (reserve requirement) yang ditentukan oleh pemerintah sebesar 5\%. maka, Bank Mandiri Syariah menunjukkan kemampuan reserve requirement diatas rata-rata industri perbankan syariah mulai tahun 2001 sampai dengan 2004 Bank Syariah Mega Indonesia selama 2 periode reserve requirementnya mendekati titik rawan, yaitu 5,2\% pada tahun 2001 serta 5,6\% pada tahun 2002. Hal ini mengindikasikan bahwa bank akan mengalami kesulitan mengembalikan simpanan pihak ketiga yang sewaktu-waktu dapat diambil, karena komposisi antara alat likuid yang dimilikinya tidak sebanding dengan simpanan pihak ketiga.

Dari tinjauan Loan to deposite ratio (indikator kerawanan dan kemampuan suatu bank) pada tahun 2001 ketiga bank masih dalam batas normal, yaitu dibawah $80 \%$. Namun pada tahun-tahun berikutnya LDR perbankan syariah mengalami peningkatan dan diatas batas normal. Bank yang LDRnya melebihi batas normal yaitu bank Muamalat Indonesia pada tahun 2002, LDRnya melebihi batas toleransi, yaitu 86\%. Untuk tahun 2003 bank Syariah Mega Indonesia (96\%). Sedangkan untuk tahun 2004 Bank Mandiri Syariah (85\%). Kenaikan ini disebabkan karena melonjaknya dana yang diterima oleh bank sehingga bank juga berusaha meningkatkan porsi dana yang disalurkan ke masyarakat. Rasio ini menunjukkan seberapa besar porsi dana yang dimiliki oleh bank yang bersumber dari dana simpanan masyarakat. Semakin besar rasio ini maka semakin besar pula tingkat resiko yang dimiliki oleh bank. LDR yang melebihi batas minimal tersebut tidak didominan oleh satu bank, hal ini mengindikasikan bahwa bank syariah berkeinginan untuk menekan LDR. Hal ini mencerminkan bahwa bank ingin mengurangi resiko kekurangan dana pada saat dana yang berasal dari pinjaman masyarakat ditarik dari bank

Kemampuan rata-rata industri perbankan untuk memenuhi permintaan kredit dengan menggunakan total assets yang dimiliki oleh bank mulai tahun 2001 sampai dengan 2004 mengalami kenaikan, hal ini mengindikasikan bahwa kemampuan perbankan syariah untuk memenuhi permintaan kredit dengan menggunakan total assets yang dimilikinya semakin menurun. Kemampuan bank dalam memenuhi kewajiban jangka pendeknya dilihat dari perbandingan aktiva yang dapat digunakan setiap saat utuk memenuhi likuiditas bank (alat likuid) terhadap dana pihak ketiga yang dihimpun bank yang harus segera dibayar pada tahun 20001 Bank Muamalat Indonesia sebesar 84,92\% Ini berarti bahwa bank mampu menjamin setiap Rp 1 pinjaman yang harus dibayar dengan 0,85 alat 
likuidnya. Hal ini mencerminkan bahwa semakin besar cash ratio, maka bank semakin likuid.

Sedangkan tahun 2002 cash ratio Cash ratio Bank Muamalat Indonesia sebesar 68,69 \% Kemampuan bank dalam menjamin setiap Rp 1 pinjaman yang harus dibayar dengan 0,69 alat likuidnya. Hal ini mencerminkan bahwa semakin besar cash ratio, maka kemampuan bank dalam membayar kewajiban jangka pendeknya dengan alat likuid yang dimilikinya semakin terjamin

Pada tahun 2003 cash ratio Bank Muamalat Indonesia sebesar 87,41 \% Ini berarti bahwa bank mampu menjamin setiap Rp 1 pinjaman yang harus dibayar dengan 0,87 alat likuidnya. Sedangkan pada tahun 2003 tersebut terjadi peningkatan alat likuid khususnya giro pada bank Indonesia. Kemampuan cash ratio pada tahun 2004 Bank Muamalat Indonesia sebesar 73,38 \% Kemampuan bank dalam menjamin setiap Rp 1 pinjaman yang harus dibayar dengan 0,73 alat likuid nya. Hal ini mencerminkan bahwa semakin besar cash ratio, maka kemampuan bank dalam membayar kewajiban jangka pendeknya dengan alat likuid yang dimilikinya semakin terjamin.

\section{e) Reserve Requipment :}

Likuiditas wajib minimum atau simpanan wajib dipelihara dalam bentuk giro di Bank Indonesia (reserve requipment) Bank Muamalat sebesar 10,661\%. Kemampuan simpanan wajib minimum yang wajib dipelihara oleh Bank Indonesia pada tahun 2002 mengalami penurunan. Reserve requipment Bank Muamalat Indonesia sebesar 5,46 \%

Pada tahun 2003 reserve requipment Bank Muamalat Indonesia besarnya reserve requipment adalah $8,42 \%$. Kemampuan simpanan wajib minimum yang harus dipelihara oleh Bank Indonesia pada tahun 2004 Bank Muamalat Indonesia sebesar 6,47\% Berdasarkan ketentuan Surat Edaran Bank Indonesia No 23/17/BPPP tanggal 28 Februari 1992, besarnya reserve requipment adalah sebesar 2\%. Namun peraturan itu sudah mengalami perubahan, yakni tertanggal 1 Februari 1996 besarnya reserve requipment adalah $3 \%$. Namun sejak tahun 1997 besarnya reserve requipment menjadi $5 \%$. Secara umum reserve requipment bank tersebut diatas $5 \%$. Namun pada tahun 2002 secara umum reserve requipment bank mengalami penurunan, namun masih diatas ambang batas $5 \%$.

\section{f) Loan to Assets Deposite Ratio}

Indikator yang digunakan untuk mengukur atau membandingkan dua komponen neraca, yaitu pinjaman yang diberikan di sisi aktiva dan dana yang diterima oleh bank, Pada tahun 2001 Bank Muamalat Indonesia sebesar 77,680\%. Loan to deposite ratio pada 
tahun 2002 bank Muamalat Indonesia sebesar 86,540\%. Kemampuan loan to deposite pada tahun 2003 Bank Muamalat Indonesia mengalami penurunan menjadi 71,720\%.

Pada tahun 2004 kemampuan bank Muamalat Indonesia mengalami peningkatan. Muamalat Indonesia sebesar 80,280 \%. Rasio ini merupakan indikator kerawanan dan kemampuan suatu bank. Sebagian praktisi perbankan menyepakati bahwa batas aman dari loan to deposite ratio suatu bank adalah sekitar $80 \%$. Namun batas toleransinya sekitar 85\%-100\% (Dandawijaya,2000:119). Rasio ini menunjukkan seberapa besar porsi dana yang dimiliki oleh bank yang bersumber dari dana simpanan masyarakat. Semakin besar rasio ini maka semakin besar pula tingkat resiko yang dimiliki oleh bank. Kenaikan yang terjadi mengindikasikan adanya lonjakan dana yang diterima oleh bank sehingga bank juga berusaha meningkatkan porsi dana yang disalurkan ke masyarakat.

\section{g) Loan to Total Assets}

Kemampuan untuk memenuhi permintaan kredit dengan menggunakan total asssets yang dimiliki bank (loan to asset ratio) pada tahun 2001 mencapai 77,68\%. Pada tahun 2002 meningkat menjadi 85,93\%. Namun pada tahun 2003 mengalami penurunan menjadi 71,72,21\%. Sedangkan pada tahun 2004 mengalami peningkatan lagi menjadi 80,28\%. Hal ini mengindikasikan bahwa kemampuan perbankan syariah untuk memenuhi permintaan kredit dengan menggunakan total assets berfluktuasi.

\section{BAB VI \\ PENUTUP}

A. Kesimpulan

1. Kemampuan bank dalam membayar kembali simpanan nasabah saat ditarik kembali dengan alat likuid (cash ratio) yang dimiliki dan besarnya diatas rata-rata industri perbankan syariah pada tahun 2001 dan tahun 2002 adalah bank Syariah Mega Indonesia. Pada tahun 2003, cash ratio bank syariah yang besarnya melebihi rata-rata industri perbankan syariah adalah bank Mandiri Syariah dan bank Muamalat Indonesia. Sedangkan pada tahun 2004, cash ratio bank syariah yang besarnya diatas rata-rata industri perbankan syariah adalah bank Syariah Mega Indonesia.

2. Kemampuan rata-rata perbankan syariah dalam memenuhi Giro wajib minimum (reserve requirement) sudah melebihi standar dari Bank Indonesia, yaitu 5\%. Namun pada tahun 2001 dan tahun 2002 reserve requirement bank Syariah Mega Indonesia dan bank Muamalat Indonesia pada tahun 2002 mendekati nilai $5 \%$. Di 
tahun-tahun berikutnya terlihat bahwa ke dua bank berusaha untuk menambah reserve requirement yang dimilikinya

3. Rasio antara seluruh jumlah kredit yang diberikan oleh bank dengan dana yang diterima bank pada tahun 2001 rata-rata dibawah 80\%. Pada tahun 2002 bank Muamalat LDR nya melebihi angka 80\%. Pada tahun 2003 bank syariah yang LDRnya melebihi standar normal adalah bank Syariah Mega Indonesia. Sedangkan tahun 2004 bank Mandiri Syariah LDRnya melampaui 80\%. LDR tertinggi dicapai oleh bank Syariah Mega Indonesia. Batas ambang 80\% menunjukkan tingkat kerawanan dan kemampuan suatu bank. Semakin besar rasio ini maka semakin besar pula tingkat resiko yang dimiliki oleh bank. Bank syariah berusaha menekan LDR nya, penekanan ini sebagai indikasi bahwa bak ingin mengurangi resiko dana pada saat dana yang berasal dari pinjaman masyarakat ditarik dari bank.

4. Kemampuan loan to assets pada tahun 2001 dan tahun 2002 yang melebihi ratarata industri perbankan syariah adalah Bank Mandiri Syariah dan bank Muamalat Indonesia. Hal ini mencerminkan bahwa bank mampu memenuhi permintaan kredit dengan menggunakan total assets yang dimilikinya diatas rata-rata industrinya. Sedangkan pada tahun 2003 LAR bank syariah yang nilainya diatas rata-rata industri adalah bank Syariah Mega Indonesia. Tahun 2004 kemampuan LAR bank Syariah Mandiri dan bank Muamalat meningkat lagi diatas rata-rata industri.

B. Saran-saran

Bank syariah merupakan salah satu lembaga keuangan yang memberikan pelayanan berdasarkan konsep syariah Islam. Dengan mayoritas masyarakat yang beragama Islam merupakan salah satu peluang bagi perbankan syariah untuk mengembangkan usahanya. Kegiatan yang sebaiknya ditingkatkan berkenaan dengan pengembangan perbankan syariah adalah dengan sosialisasi, edukasi dan promosi dan bekerja sama dengan lembaga terkait untuk meningkatkan preferensi masyarakat terhadap perbankan syariah. Dari sinilah maka bank syariah dapat lebih mengoptimalakan penarikan dana dan menyalurkannya kembali dana tersebut ke masyarakat.

\section{DAFTAR PUSTAKA}

Abdullah M. Faisal,. Drs, MM. 2003. Manajemen Perbankan (Teknik Analisis Kinerja Keuangan Bank). Malang: UMM Press.

Antonio, Muhammad Syafi'i. 2001. Bank Syariah : Dari Teori Ke Praktik. Jakarta: Gema Insani Press. 
Arifin, Zainul Drs. MBA. 2002. Dasar-dasar Manajemen Bank Syariah. Jakarta Alfabet.

BI 2001. Direktori Perbankan Indonesia 2001. Jakarta : Bank Indonesia

BI 2002. Direktori Perbankan Indonesia 2002. Jakarta : Bank Indonesia

BI 2003. Direktori Perbankan Indonesia 2003. Jakarta : Bank Indonesia

BI 2004. Direktori Perbankan Indonesia 2004. Jakarta : Bank Indonesia

BI 2005. Direktori Perbankan Indonesia 2005. Jakarta : Bank Indonesia

Dandawijaya, Lukman Ir. Drs. 2003. Manajemen Perbankan. Jakarta: Ghalia Indonesia

Hasan, M. Iqbal, Ir. Drs. 2003. Pokok-pokok Materi Metodologi Penelitian dan Aplikasinya. Jakarta: Ghalia Indonesia.

IAI. 2002. Kerangka Dasar Penyusunan dan Penyajian Laporan Keuangan Bank Syariah. Jakarta: Salemba Empat.

Kuswandi, Daniel S. SE, AK, MBA, dkk. 1997. Akuntasi Perbankan (Akumulasi Bank Dalam Valuta Rupiah). Jilid I. Jakarta: Institut Bankir Indonesia.

Muhammad. 2001. Sistem dan Prosedur Operasional Bank Syariah. Yogyakarta: UII press

-----, 2001. Teknik Perhitungan Bagi Hasil di di Bank Syariah. Yogyakarta: UII Press

Santoso, Ruddy Tri. 1995. Prinsip Dasar Akuntasi Perbankan. Yogyakarta: Andi Offset

Sumarso, SR. 1992. Akuntasi : Suatu Pengantar Jilid I. Jakarta: Rineka Cipta.

Surat Edaran Bank Indonesia Nomor 2/5 BPPP Tanggal 29 Mei 1993 Tentang Tata Cara Penilaian Tingkat Kesehatan Bank.

Surat Keputusan Direksi Bank Indonesia Nomor: 30/11/KEP/DIR Tanggal 30 April 1997.

Syamsudi, MA.Drs. Lukman.1998. Manajemen Keuangan Perusahaan. Jakarta: PT. Raja Grafindo Persada.

Surat Keputusan Direksi Bank Indonesia Nomor 30/227/KEP/DIR Tanggal 19 Maret 1998

Surat Keputusan Direksi Bank Indonesia Nomor 31/148/KEP/DIR Tanggal 12 November 1998.

Undang-undang Nomor 7 Tahun 1992.

Undang-undang Nomor 10 Tahun 1998

www. BI. Co. id 
*) Jamal Lullail, SE., MM., Dosen Fakultas Ekonomi UIN Malang 